\title{
Formation of Elite in Russia: Conflict and Consensus
}

\author{
Evgeniy V. Suslov
}

Valeriy B. Golubev

Sergei A. Zhyravlev

Vitaliy T. Mihailov

\author{
Mari State University, Yoshkar-Ola, Russia \\ esuslov@mail.ru
}

Doi:10.5901/mjss.2015.v6n3s7p71

\begin{abstract}
Writing of the article is determined the following reasons. Firstly, the increasing role of elites in the modern global world needs strategic decisions in acute shortage of time. Secondly, the growing role of administrative and political elites concentrated in the executive authorities in the period when the role of parliamentarism and political parties weakens regardless of political regimes. Thirdly, the actual growth of the presidency role in Russia, when a semi-presidential form of government is actually transformed into a super-presidential, which led to the reformation in elite-formation. The authors are aimed to reveal the causes that led to creation of a elite-formation-model typical of Russia. The authors come to the conclusion that Russia belongs to the category of states where mobilization model of development dominates. It was established due to natural and geographical features of the country and the necessity to preserve the territorial integrity of the state as well as to ensure its safety. The Soviet administrative-bureaucratic system formed in conditions of external threats and lack of resources for development, led to the creation of specific system elite-formation, called nomenclature. External stability of the Soviet nomenclature system of elite-formation turned out to be misleading in reality as it couldn't resist to internal and external challenges of the late 80-ies of XX century. The process of elite-formation in Russia has an asymmetrical wave-like nature, which is reflected in successive phases of conflict and consensus. During this phase of the conflict phase often becomes latent in nature, getting a form of consensus.
\end{abstract}

Keywords: elitology, elite recruitment, mobilization and innovative types of development, decisional criterion, the meritocratic principle, nomenclature, incorporation in the elite pool.

\section{Introduction}

In a wide range of contemporary research trends in political science the phenomenon of elite and, consequently, the processes of elite formation occupy a prominent position. The reason of research preferences is in indisputable awareness of the absolute truth that the role of elites in the modern global world that needs to be strategic and at the same time deliberate decisions at deficiency of time is extremely significant. Of course, it is so provided that the speed and efficiency of decision-making process are directly dependent on the quality of the elites.

Prevailing in the modern world trend, not excluding Russia, is the pattern: «the powerful elites become even more powerful» (Gaman-Golutvina, 2011). In contrast to the system of powers separation we can witness the weakening influence of the institutions of parliamentarism and political parties which is followed by strengthening of the role of the executive power. This trend has covered not only post-socialist countries, but also the countries with functioning democratic political regimes. According to the famous American researcher of elites J. Highley, we are not talking about a single incident, but about the tendency of changing practices of political leadership in favor of "cesarien" ones not only in the USA but also in European countries (Higley, Pakulski, 2007). The de jure semi-presidential (mixed) form of government in Russia having been established in accordance with the Constitution of the Russian Federation in 1993, in the last decade, has rapidly transformed into the de facto a super-presidential form of government, which led to the reformation and the model of elite formation. No doubt, the problem attracts the attention of Russian researchers.

An additional factor making Russian elitology special is its nearness to the community of "the elite", knowledge of the secrets of their personal life, awareness of non-public issues.

However, despite the personalistic nature of politics in Russia in all its historical duration, which by definition ought 
to have caused a research interest in the political elites, on the contrary, at the institutional level, there was no scientific interest in the problems of elites. As noted by the famous Russian elithologist O. Kryshtanovskaya, "Until 1989 any issues associated with the study of the ruling group of the country, were a mystery. That time not only researches, but also the use of the word «elite were banned in the USSR. The Soviet people were not supposed to know about the lives of those who ruled the country» (Kryshtanovskaya, 2005). As it turns out even when our country wasn't talking about them aloud for ideological and for the reasons of their personal safety, the interest in potestera elites and to different facets of the process of recruitment of elites remained.

In the post-Soviet years in Russia there was an elitological boom owing primarily to the relatively high level of openness of power which really was trying to understand the advantages and disadvantages of different models of elite formation and the possibility to use one of them in actual political practice. So to a certain extent researchers' preferences of the topics of exactly elithological character to other topics of researches were encouraged.

Due to extreme inconsistency and permanent conflict of the policy itself the processes of elite formation, operation and rotation of elites being the most important substantive components of the political process are being penetrated with the conflicts of different profundity, scope and intensity. Not all of them are of destructive nature, however, some conflicts, not being institutionalized, i.e. having gone beyond the "rules of the game", or latent conflicts, subject to deformation and, ultimately, destroy the state of consensus of elite institutions.

Therefore, the aim of our research is to identify the causes that contributed to the creation of typical for Russia a mobilisation model of formation where the weakly defined boundaries of periods of conflict and consensus succeeded each other, thereby creating a certain balance between them. We also have to figure out why the consensus in the Soviet (Russian) elite formation outwardly seemed and seems stable, when in fact it was and remains unstable depending on such factors as the condition of the hydrocarbon raw stock, life expectancy and physical state of the first persons of the state, as well as the possibility of a conspiracy of the elites. It is also important to understand potential transition in Russia from a mobilization model of development to innovation, providing a model change and the formation of ruling elites.

\section{Materials and Methods}

In modern political science, there is no single interpretation of the term "elite". They were not identical even in the classical concepts of elites in the late XIX - early XX centuries which were developed by famous Italian political thinkers G. Mosca and V. Pareto. So, Mosca considered the most important criterion of belonging to the elite the ability to govern other people and the superiority of the moral, intellectual and material characters. He always thought of these people to belong to the political class. V. Pareto saw in the elite the selected minority which at all times effectively ruled the world. Pareto has divided the elite into ruling and non-ruling counter-elite which are in a state of eternal conflict, but are forced to obey a particular institutional order for the sake of self-preservation.

Moreover, Pareto linked social development with the circulation of two types of elites: "the Fox" with their "soft" methods of leadership and the lions, which are characterized by strong measures, based primarily on power. According to Pareto, the circulation of elites is taking place because the equilibrium of the social system requires a constant process of replacement of elites due to the fact that they having achieved power fall into decay and no longer meet the needs of the leadership of a society.

Valuable for our research conclusion is the statement of $\mathrm{V}$. Pareto that the termination of circulation leads to degeneration of the ruling elite and the revolutionary break-up of the system. It is important to note that both Mosca and Pareto, not directly addressing the concepts of "conflict" and "consensus", in fact, confirm their alternating presence in the functioning of the elites.

Continuing the discussion about the nature of elites, being laid by classics, a famous Russian elithologist $\mathrm{O}$. Gaman-Golutvina notes that "the common denominator of virtually all definitions is the idea of exclusivity being determined by this category of persons, great ideas about the ideal principles of recruitment elite, as well as the meaning and tone of the axiological accent, are different: some researchers believe that the authenticity of the elite is conditioned by the nobility of origin, while the others consider this category to be the wealthiest people, other people imply them to be the most talented ones: joining the elite is a function of personal merit"(Gaman-Golutvina, 2006). More preferable we believe the latter interpretation, which is a functional approach to the assessment of the elites.

Since under the proposed article we are interested in, first of all, the political elite, functional theoretical "optics" in the allocation of the political elite from the General structure of the elite allows you to give preference decisional (from the English «decision») criterion, based on the idea of belonging to the elite, on the basis of actual participation in decision making process. Speaking about strategic decisions, then we are dealing with higher political elite of the country. If the level of the decision is lower, then, accordingly, there will be the elites dominant in economic, military, information and 
other segments, as well as at regional level. However, interpreting the Russian process of elite formation in which informal practices prevail, we cannot limit ourselves only by decisional criterion without taking into account other criteria. Thus, the positional criterion is characterized by belonging of an individual to the elite basing on his / her position in the hierarchy of power. The correlation of elites on this principle does not show the direct impact on decision making process. It can be nominal or indirect.

Necessary from the point of view of the choice of the theoretical foundations of our article is the appeal to the concept of "development type" because "its value is such that the researchers reasonably compare its heuristic potential to such categories as socio-economic formation, the method of production" (Gaman-Golutvina, 2006). The type of development of a society accumulates the correlation between the development of a society and the resources that can be used to solve the formulated problems. It is accepted to speak about innovation and mobilization types of development, between which intermediate forms may be located. It is the preference for a particular type of development predetermines the type of a political organization of a society and, accordingly, what model of elite formation will be selected.

Characteristic feature of the innovation type of development is a relatively stable balance between present resources and growing needs, the dominance of economic factors in the form of the account of the state economic interests by non-state actors of economic activity. Of course, this type of development is not without some drawbacks, which is reflected in periodically arising economic crises due to sudden imbalance between the capacity of the economy and the needs of the population. However, periods of slumps in the innovation economy are accompanied by periods of growth. The conclusion about the presence of long periods of conjuncture in the global capitalist economy, made in the early 20s of the XX century by the famous Russian economist N.D.Kondratyev, allowed coming to the conclusion that the innovation economy, cyclically entering phases of crisis, recovers even stronger. One of the major reasons of dynamic stability of innovative economy is the formation in its long period of its establishing the system of competitive elitism. The concept of "competitive elitism" belongs to the famous British political scientist David Held. In our opinion, it was the search for and the detection of the optimal model of elite formation, which, according to D. Held, represents a balance between power and justice, authority and law, competent governance and national sovereignty" (Held, 2014).

The deficiency of resources on the one hand and the limited capacity on the other hand, demonstrating the long period of their imbalance, lead to mobilization type of development, which, unlike an innovation type, is focused first of all on the realization of interests of the state as opposed to the interests of non-state actors of economic activity. At the same time the state pursues quite rewarding goals of providing security and defence of the country, its accelerated development in the context of resource deficiency. The resources used by the government to achieve the goals of predominantly political nature have extraordinary forms. They become realized with the help of the instruments of force and violence. The result of the mobilization development is the strengthening of the role of the repressive apparatus.

How does this trend affect the processes of elite formation? If we assume decisional criterion for the matching of potential candidates to the elite pool, then this community happens to be extremely few in number and in addition to have a negligible impact on the process of making important decisions.

The ratio of conflict and consensus, their temporal characteristics within the frames of innovation and mobilization types of development will also be different in form and content. Permanent present in a mobilization type of development contradiction arising between resources and capabilities increases to the level of conflict and at the relatively short time is being solved by application of the state, its key political actor - violence and force. However, the powerful form of conflict resolution leads to fear, apathy and distrust of authority institutions. The coming phase of consensus using a mobilization model, in our opinion, represents the forced consent of the majority of citizens with the government's course and is unsustainable. Consensus does not mean getting rid of the conflict. The nature of the conflict is more complex. Due to the fact that the conflict is a necessary condition of development, then, being seemingly resolved, however, continues to be present in various spheres of human interaction in a latent form.

\section{Results and Discussion}

Identification of the type of development provides researchers with key to the model of elite formation, determination of the causes that contributed to its establishment. Judging from the characteristics identified in the interpretation of the mobilization type of development, Russia belongs to the category of states, where this model of development dominates. The range of reasons for the formation of this model is not very wide and it comes down to the arguments of natural geographic and mobilization characters. In other words, it is about the need of Russian rulers to appeal to extraordinary measures and actions for the sake of preserving the territorial integrity of the state and to ensure its safety.

So, the Russian philosopher S. Soloviev believed that "the most important factor that determined the bureaucratic 
nature of the organization of the Russian authorities were very unfavorable demographic and climatic conditions", and besides "there was a non-optimal ratio of vast territory and small population" (Soloviev, 1989). S. Solovyov is echoed by I. Solonevich: "the history of Russia is the history of overcoming geography of Russia" (I. Solonevich, 1991). As an argument in favor of the climatic version of the mobilization type of development of Russia O. Gaman-Golutvina, referring to the American historian and political scientist R. Pipes, who is difficult to be suspected of being sympathetic to Russia, writes: "Pipes emphasizes the impact of adverse climatic conditions on the course of Russian history, noting that the most important result of the location of Russia is poverty of the soil and the extremely short period suitable for farming: $4-5$ months a year unlike 8-9 months in Western Europe"(Gaman-Golutvina, 2006).

Obviously, adverse natural conditions doubled with the deficiency of resources demanded from the producers of material values (mostly peasants) mass dedication and concentration of forces to produce a sufficient amount of products of labor. Work at the limit of human endurance with the use of primitive tools covered practically the entire adult population of pre-revolutionary Russia. The ability of the peasant population of the country to other occupations, except food production, was extremely limited. From the end of XIX century it was allowed in the form of migration to factories, mainly producing military products. It was a different, militarized face of the mobilization model of development of the state, which became a military state in which, according to the Russian historian and jurist B. Chicherin "service to the throne is a function of not only one class but of all the subjects that are attached to places of residence or service. And above it all the government with unlimited power reigns" (Speransky, 1961).

Being employed with the care about survival, both in the village and in the city, the Russian citizens did not have a sufficient amount of free time to indulge their intellectual development and accumulation of cultural capital. Meanwhile, the amount of free time is one of the most important factors of deliberated involvement in politics, if by politics one understands the relationship between policy actors regarding the distribution of power. The problem of free time and was in the conditions of the first decades of existence of the USSR, when the enthusiasm of the Soviet people was unprecedented. Mobilization of personal resources was directed to the maximum realization of interests of the state.

Historically, the prevailing factor in the predisposition of the Russian state to the mobilization model of development is its status as a system in the unfavorable, and often aggressive, foreign policy environment. Emphasizing the forced nature of constant readiness of Russia to war, the Russian philosopher S. Soloviev noted: "Russia is a huge continental state, which is not protected by natural boundaries, open from the East, South, West ... Based in such a country, the Russian state from the beginning was condemned to lead constant heavy exhausting struggle with the inhabitants of the steppes ... poor scattered on vast territories people was constantly with incredible difficulty to collect its strength, to give a hard-won last kopeck to get rid of the enemies that threatened from all sides"(S. Soloviev, 1989).

Being forced to lead long-term defensive wars due to foreign policy circumstances, Russia, according to a German diplomat Herberstein at the court of Vasily III, created the impression that for Muscovy peace, but not war was an incident» (Kluchevsky, 1993). Wars were a heavy burden for the state treasury which was not weighty even in the best times. There were such times when military expenditure of Russia was twice as high as the state budget. It was so during the Russian-Turkish war of 1877-1878. O. Gaman-Golutvina believes that "The consequences of the defeat in the Russian-Japanese war and the failures of military involvement in the First world war fatally affected the political development of the Russian Empire, bringing it to the brink of economic collapse" (Gaman-Golutvina, 2006).

Mobilization trend could change when Bolshevists came to power because external challenges have not diminished. Moreover, it is said that the idea of world revolution dominated in the USSR in the first years after the Civil war. It required significant expenses for defense and security of the country.

Keeping friendly Communist parties and underground workers' parties was quite consuming as they potentially represented a force ready to class battles on the Soviet side.

Administrative-bureaucratic system was formed in the face of external threats and lack of resources development and led to specific elite-formation system that was called nomenclature. Milovan Dzhilas, a former member of Yugoslavia Communists League who held senior positions in the leadership of the Central Committee, being the author of the book "The New Class" developed the theory of nomenclature, which gave a comprehensive characteristic of this phenomenon. «After the socialist revolution victory, the apparatus of the Communist party was transformed into a new ruling class. This class of party bureaucracy monopolizes power in the state. The process of rebirth follows. The former dedicated revolutionaries who demanded the widest democratic freedoms, being in power turned into ferocious reactionaries. Ongoing industrialization and cultural dissemination were the positive aspects in the activity of the new class in the economically underdeveloped countries. However, its bossing in the economy is very harmful, while the culture has the nature of political propaganda» (M. Voslenskiy, 1991). Extensively developed economy was thriving for some period, however, its capacities were limited.

The Soviet citizens were quite satisfied with nomenclature for seventy years of the Soviet rule. It might have been 
estimated as the consensus of the dominant party majority (Russian Communist Party, All-Union Communist party, Communist Party of the Soviet Union), which used to be the state, its supporting structure. The collapse of the USSR and the nomenclature happened almost simultaneously, proving that the external stability of the Soviet system of eliteformation, in fact, turned out to be deceptive.

There was an accumulation of destructive conflict potential, both in the political system and in the system of eliteformation. This process was accelerated by two factors. Firstly, drop in prices for hydrocarbon raw materials in the years of Leonid Brezhnev's late ruling led to strategic resources exhaustion of the USSR. Secondly, the arms race imposed by the West, primarily by the USA weakened the Soviet Union, which rashly faced this foreign policy challenge. Thirdly, the absence or weak elites' recruitment was far from meritocratic principle of elite-renovation.

The so-called "elite revolution" took place in the era of B.N. Yeltsin's presidency in Russia. It meant that the attempt of mobilization model development failed in favor of innovative development of the country. A new elite organization model was different from the previous ones. First of all, it was the principle of elite pluralism, when "windows of opportunities" opened for those, who were in the right time in the right place. Referring to B. N. Yeltsin, the President of the Russian Federation, relatively young people were incorporated in the elite pool (B. Nemtsov, Sergey Stankevich, M. Prusak, etc.). However, these changes were superficial, without affecting the mobilization model of development. "Yeltsin, being an absolute Bolshevik, in fact, created a precedent governing the country through presidential decrees. Resolute Presidents' behavior, who had won the clownish State Committee of the State of Emergency, impressed many people in Russia who thought that "total ideology of communism had to come to an end "here and now". The haste and zeal in the events and thoughts had a "disservice" for mobilizing liberalism» (E. Suslov, 2006).

The conflict at this stage of the Russian history occurred between the old nomenclature and oligarchs, the latter being first given the opportunity to influence political processes by means of informal channels of communication. The incorporation in the elite pool on involuntary decisional principle for party representatives was the result of collusion, i.e. consensus between losing legitimacy Yeltsin and Russian big business that used to sponsor his election campaign in 1996.

Businessmen Vladimir Potanin, Boris Berezovsky, Leonid Nevzlin and others with predominantly negative opinion characterized by extreme inconsistency and sometimes bias in mass consciousness held powerful government positions. We believe that business community like any other stratum in the society structure should position itself as a political actor, however, its influence cannot be unlimited, infringing other strata options.

The line of confrontation between elites and non-elites, between elitism and egalitarianism, which led to the "mass revolt" and to the partial establishment of democratic values and democracy forms is another plane of conflict. Consensus used to be and still remains traditional for Russia.

It is not coincidence that elite is assessed in unfavorable way in contemporary Russia. "The term "elite" does not always mean the real elite. In the Soviet times, the party-state nomenclature did not call itself the elite. They identified themselves as "the mind, honor and conscience" (V. Golubev, 2013).

Moreover, according to E. Dubko, "elite used double standards. So, if the masses being "little people" do the same thing as elites do, act as individuals, elites treat their behavior as a threat to society, challenge, unforgivable arrogance and an act of rebellion.... Heartlessness and indifference are the impressive features of the new elite. It confirms the proverb that "a man with fully belly does not understand the hungry". In response, the masses do not protect the elite" (E. Dubko, 2005).

A trend to delegitimize elites is recorded by scientists-sociologists in the materials of large-scale studies.

So, Mikhail Afanasyev in a survey on the Russian elite groups with sample sizes of 1003 respondents came to the conclusion that "the Russian elite, firstly, professes consistent philosophical relativism. It is not sensitive to the normativeaxiological approach, to reality and its own activities. Secondly, the Russian elite have adopted a Western lifestyle and living standards, but do not accept the Western rules of civil liability, public openness and public integrity. Thirdly, it is not interested in building a society based on open competition. It is interested in the revenue status and privileges" (M. Afanasyev, 2011). Hardly-concealed conflict between elites and non-elites remains. It cannot be saved by nature. Institutionalization of this kind of conflict, i.e., its occurrence within the "rules of the game" established on the basis of a definite social contract is the effective way to maintain it in a manageable state. Elites' recruiting from non-elite population by meritocratic qualities is a reliable means of reducing the conflict level between the parties of conflict.

In connection with Vladimir Putin's coming to power following Boris Yeltsin's early resignation from the position of the President of the Russian Federation the opportunities of Seven Bankers' Cabal - the Corporation's financial and industrial capital - on incorporation into the highest elite have almost been exhausted. From the beginning of his second term the Russian President Vladimir Putin began to build the phenomenon of the "equidistance line" business from the "vertical of power", which deprived business opportunities to participate in making important political decisions. 
Putin's elite was formed with representatives from the military and civil bureaucracy. The first category of the nominees was mainly represented by the security services ("chekists"). The second consisted of officials at various levels, who worked with Putin in the city hall of St. Petersburg.

The nomination for high public office on the principle of patriotic identification and previous joint occupation was no exception to the rule. More likely, it showed a deficit of qualified personnel in the team of the new President and his desire to "rely on reliable and personally dedicated people under conditions of acute intra-elite struggle" (O. Gaman-Golutvina, 2006).

Intra-elite conflict has always been typical for the Russian authorities. Sometimes it had the short-term nature of the supporters of mobilization and innovative types of development. For example, in Mikhail Gorbachev's era, when A. N. Yakovlev, the architect of perestroika, and E. K. Ligachev, an ardent supporter of preserving the status quo were the members of the Political Bureau of the Communist Party of the Soviet Union. Intra-elite struggle, basically, had a latent character. Not being allowed in the early stages it led to the attempted coup in August 1991 organized by the supporters of restoring the old political order in the country. However, intra-elite conflict in Vladimir Putin's era without reaching the extreme limits that honors the President's flexibility, is reduced to the conflict for a place near the President. The vicinity to the first person in the hierarchy of political power demonstrates the power and influence of the winning clan, and at the same time satisfies the defeated by their disadvantaged position.

A kind of elite consensus based on two fears is formed. On the one hand, the fear of losing their position, status and be excorporated (being expelled) from the elite pool. On the other hand there is fear to lose control over society in the period of the economic crisis with political consequences.

Currently, the Russian government is dominated by a "party of security forces" (P. Ivanov, Sergey Shoigu, Igor Sechin, V. Ivanov), which clearly outplayed the "party of liberals" (Dmitry Medvedev, Igor Shuvalov, A.Dvorkovich). The latest, trying to save face, sometimes use rhetoric types of the innovative development model. However, they cannot afford more. In our opinion, the reason is in the existing collusion of elites, based on the Putin's recognition as an undisputable national leader. The following points would have been impossible without his personal involvement. Firstly, it is the career of any individual team member. Secondly, it is the existing configuration of the elite pool capable of supporting expected in mass consciousness political order and ensuring the mobilization type of development.

Evolutionary transition to an innovative development model, assuming the existence of a power elite able to find adequate responses to the growing challenges of the time will be made at some not very distant mobilization stage of development when extensive resources will significantly dry out.

\section{Conclusion}

The study of elite-formation in Russia provides a basis for formulating the following conclusions:

- Exceptional research interest in problems of elite-formation is caused by the increasing role of elites in modern global world that needs to take balanced strategic decisions despite the acute shortage of time;

- Taboo on the elites study in the USSR had ideological reasons and reasons of personal safety, but the interest in power elites was always important;

- The reason to prefer the mobilization type of development is the shortage of resources and limited opportunities that led states to extreme solutions of the problems by means of force and violence;

- Dynamic stability of the innovative economy and politics is the system of competitive elitism formation during the long years, based on the balance between force and law, government and law, the competitive governing and national sovereignty;

- Russia belongs to the category of states, where mobilization model of development dominates. It was internally established due to natural and geographical features of the country and the necessity to preserve the territorial integrity of the state and in the interests of its security;

- The Soviet administrative-bureaucratic system, naturally formed in the period of external threats and lack of resources for development, led to the creation of elite-formation specific system that was called nomenclature;

- The external stability of the Soviet nomenclature system of elite-formation in reality turned out to be misleading as it could not resist to internal and external challenges of the late 80-ies in XX century;

- "Elite revolution" took place during the first Russian President B.N. Yeltsin's rule. It was a period when "windows of opportunities" opened for incorporating into the first Russian elite pool for the ordinary Russian citizens;

- Recruiting elites from non-elite population according to meritocratic qualities is a reliable means of reducing conflict level between elites and non-elites; 
- Intra-elite conflict was a constant companion of the Russian authorities. It had either short-term nature of the mobilization supporters and innovative types of development, or more often was aimed at maintaining elite status surrounded by the first person and the preservation of personal comfort.

\section{References}

Afanasyev, M.N. (2011). The Russian Elite and Paradigms of Development: The Request for a New Course? / Elite and Society In a Comparative Dimension. Moscow, Russian political encyclopedia (ROSSPEN).

Gaman-Golutvina, O.V. (2011). Elites and Society at the Crossroads: Collection of Articles/ M.: Russian political encyclopedia (ROSSPEN).

Gaman-Golutvina, O.V. (2006). Political Elites in Russia: Stages of Historical Evolution. Moscow, Russian Political Encyclopedia (ROSSPEN).

Golubev, V.B. (2013). On the Law, Human Rights and Sexism: Monograph / Mari State University. Yoshkar-Ola.

Dubko, E.L. (2005). Political Ethics. - Moscow, Academic Project; Trixta.

Held, David (2014). Models of Democracy. Moscow.

Higley, J. Pakulski, J. (2007). Forceful Leaders and Leonine Elites in Liberal Democracies // Comparative Sociology, 6.

Klyuchevsky, V.O. (1993). The Russian History. The Full Course of Lectures in Three Books. Moscow: Thought.

Kryshtanovskaya, O. (2005). Anatomy of the Russian elite. - Moscow: Zakharov.

Soloviev, S. (1989). Reading and Stories on the History of Russia. - Moscow: Pravda.

Solonevich, I.L. (1991). People's Monarchy. Moscow.

Speransky, M.M. (1961). Projects and Notes. Moscow, Leningrad.

Suslov E.V. (2006). Prospects of Liberalism in Russia / Spiritual Sphere of the Society: Materials of the Scientific Conference on the Results of the NIR 2006 / Mari State University. Yoshkar-Ola.

Voslensky, M.S. (1991). Nomenclature. The Ruling Class of the Soviet Union. Moscow, "Soviet Russia." collab. with MP October. 
